\title{
Phosphorus Management and Water Quality Problems in Grazingland Ecosystems
}

\author{
Maria L. Silveira, ${ }^{1}$ Joao M. B. Vendramini, ${ }^{1}$ and Lynn E. Sollenberger ${ }^{2}$ \\ ${ }^{1}$ Range Cattle Research and Education Center, University of Florida, 3401 Experiment Station, Ona, FL 33865, USA \\ ${ }^{2}$ Agronomy Department, University of Florida, 2185 McCarty Hall, Gainesville, FL 32611, USA
}

Correspondence should be addressed to Maria L. Silveira, mlas@ufl.edu

Received 11 March 2010; Revised 14 June 2010; Accepted 14 July 2010

Academic Editor: Bernd Lennartz

Copyright ( $) 2010$ Maria L. Silveira et al. This is an open access article distributed under the Creative Commons Attribution License, which permits unrestricted use, distribution, and reproduction in any medium, provided the original work is properly cited.

\begin{abstract}
Phosphorus management in grazingland ecosystems represents a major challenge of agronomic and environmental importance. Because of the extensive acreage occupied by grazinglands, decisions concerning pasture fertilization and nutrient management in forage-based livestock systems are crucial to both farmers and regulatory agencies. The purpose of this paper is to provide an overview of the literature relevant to pasture P fertilization and the potential impacts on water quality. There continue to be uncertainties regarding interrelationships between pasture management and water quality issues. Despite the extensive body of literature on nutrient transport from grazinglands, limited information is available on the relationships between land use, transport potential, water management, and climatic conditions affecting nutrient losses at a watershed scale. As agriculture continues to modernize and intensify, public concerns about the impacts of plant nutrients on environmental quality will likely increase. Managing water quality protection and profitable agriculture will be a major challenge for the next generations.
\end{abstract}

\section{Introduction}

A total of 17 elements are considered essential for the growth of higher plants [1]. These include carbon (C), hydrogen $(\mathrm{H})$, oxygen $(\mathrm{O})$, nitrogen $(\mathrm{N})$, phosphorus $(\mathrm{P})$, potassium $(\mathrm{K})$, calcium $(\mathrm{Ca})$, magnesium $(\mathrm{Mg})$, sulfur $(\mathrm{S})$, boron $(\mathrm{B})$, manganese $(\mathrm{Mn})$, copper $(\mathrm{Cu})$, zinc $(\mathrm{Zn})$, molybdenum $(\mathrm{Mo})$, iron $(\mathrm{Fe})$, chlorine $(\mathrm{Cl})$, and nickel $(\mathrm{Ni})$. Carbon, $\mathrm{N}$, and $\mathrm{O}$ are obtained from the air and soil water, while the other 14 are supplied by the soil. Nitrogen, P, and, K are considered "primary nutrients" because they are taken up by plant in the largest amounts. Calcium, $\mathrm{Mg}$, and $\mathrm{S}$ are considered "secondary nutrients" and are taken up in the next largest amounts. Iron, $\mathrm{Mn}, \mathrm{Zn}, \mathrm{Cu}, \mathrm{B}, \mathrm{Mo}, \mathrm{Cl}$, and $\mathrm{Ni}$ are required by the plants in very small amounts and are known as "micronutrients". Regardless of the class to which they belong, all essential nutrients are equally important for plant growth.

Soil fertility is a key component in sustainable forage production systems. Because most of the essential plant nutrients are supplied by the soil, as soils become nutrient deficient, forage yield and quality can be significantly affected. Most soils in the world are deficient in more than a single essential plant nutrient, so fertilization is generally necessary to improve and maintain forage production.

Nitrogen is often a limiting nutrient in grassland systems and is typically applied to pastures as commercial fertilizer, animal manure, or organic amendments. Biological fixation of atmospheric $\mathrm{N}$ by forage legumes can also provide adequate amounts of $\mathrm{N}$ to sustain forage and livestock production. Phosphorus and $\mathrm{K}$ can be included in fertilizer blends and applied along with $\mathrm{N}$. Calcium and $\mathrm{Mg}$ are usually supplied to forage crops through liming. Sulfur is often associated with $\mathrm{N}$ and $\mathrm{P}$ fertilizers (i.e., ammonium sulfate and triple superphosphate). Micronutrients are typically present in adequate amounts in the soil and are seldom applied to forage crops. However, under high soil $\mathrm{pH}$ conditions $(\mathrm{pH}>7)$, Fe and $\mathrm{Zn}$ may become deficient [2]. Conversely, under acidic conditions $(\mathrm{pH}<4.5)$ some elements such as $\mathrm{Al}$ and $\mathrm{Mn}$ can become toxic to the plants. 
Phosphorus fertilization is a vital component of modern agriculture. However, while adequate levels of $\mathrm{P}$ in soils are essential to grow crops, $\mathrm{P}$ has the potential to induce eutrophication in surface waters. As $\mathrm{P}$ accumulates in soils in response to excessive fertilizer, animal manure, or municipal waste application, $\mathrm{P}$ may become susceptible to transport via surface runoff and subsurface leaching. Phosphorus fertilization continues to be controversial and a topic of agronomic and environmental importance in various agricultural production systems. Current fertilizer management strategies for forage crops are aimed at balancing agronomic requirement of crops while reducing the risks of nutrient accumulation and subsequent transport to the environment. While research has clearly demonstrated that past and current pasture fertilization history can have serious consequences to water quality [3,4], studies have also shown that proper fertilization management may pose no environmental threat to surface waters $[5,6]$.

Highly weathered soils from subtropical and tropical regions often exhibit low $\mathrm{pH}$ and are considered "acidic" and lime is frequently applied to raise soil $\mathrm{pH}$. Lime also serves as a primary source of $\mathrm{Ca}$ and $\mathrm{Mg}$ to pastures. By raising the soil $\mathrm{pH}$, macronutrient availability is typically increased. However, at excessively high soil $\mathrm{pH}$, micronutrients become less available and forage production can be affected.

Maintenance of adequate soil $\mathrm{pH}$ is an important step in soil fertility programs for forage crops. Soil $\mathrm{pH}$ controls nutrient availability to plants, root development, and fertilizer use efficiency. Optimum soil $\mathrm{pH}$ promotes better root growth, which, in turn, results in more efficient fertilizer and water utilization by the plants. Research has shown that N, P, and $\mathrm{K}$ fertilization efficiency may be increased considerably when soil $\mathrm{pH}$ is within the adequate range [7].

Forage crops require different soil fertility conditions and target $\mathrm{pH}$ varies according to the forage species. In general, warm-season grasses are more tolerant to soil acidity than legumes. Reference [8] indicated that the optimum soil $\mathrm{pH}$ for the majority of the forage grasses growing in the southern U.S. ranged from 5.0 to about 6.0. Liming frequency as well as application rates will depend on the soil's characteristics and management practices. For instance, $\mathrm{N}$ fertilization rate and source and decomposition of organic materials may contribute to soil acidity.

From both agronomic and environmental perspectives, it is critical to understand the amounts and forms of nutrients present in the soil. Soil testing is still the best management tool to monitor soil fertility levels. Routine soil tests can help identify nutrient deficiencies and inadequate soil $\mathrm{pH}$. Similarly, soil test results can also indicate which nutrients are present at adequate levels in the soil so fertilizer can be omitted. In addition to the cost savings by only applying the required fertilizers, losses and environmental problems associated with off-site movement of soil nutrients can be minimized. Based on soil test results, cost-effective fertilization programs can be developed to meet forage nutrient requirements and minimize production costs.

In addition to soil tests, tissue analysis has been recently incorporated into soil fertility programs of major forage crops in the United States. In Florida, for instance, the process of obtaining a recommendation for $\mathrm{P}$ fertilization of established bahiagrass (Paspalum notatum L. Fluegge), the most abundant forage crop in the state, has recently incorporated tissue testing [9]. The basic principle involved when using tissue analysis is that forage yield will be limited at a critical nutrient concentration for each specific crop. In the case of bahiagrass growing in Florida soils, critical tissue $\mathrm{P}$ concentration was identified as being $1.5 \mathrm{~g} \mathrm{~kg}^{-1}$ [10]. [11] suggested that $90 \%$ of maximum bermudagrass [Cynodon dactylon (L.) Pers.] yields were obtained when average tissue $\mathrm{P}$ concentration was $2.0 \mathrm{~g} \mathrm{~kg}^{-1}$. A critical value of $2.6 \mathrm{~g} \mathrm{~kg}^{-1} \mathrm{P}$ has been estimated as the critical limit for dallisgrass (Paspalum dilatatum) [12]. Similarly to bahiagrass $\mathrm{P}$ fertilization work conducted in Florida, future research is being designed to identify critical tissue concentrations for other forage crops and nutrients. When used in conjunction with soil testing, tissue analysis has potential to be a useful diagnostic tool for developing nutrient management programs that predict when crops need additional nutrients while avoiding negative impacts on the environment.

\section{Nutrient Cycling in Forage Systems}

Nutrients can enter forage systems as fertilizer, animal feed, and through atmospheric deposition. In contrast, nutrients can be exported from pastures as animal product, harvested forage, and via off-site nutrient transport. When inputs exceed the removal of nutrients from the system, nutrients will likely build up in the soil increasing the risks associated with nutrient losses. A key component of sustainable forage systems is to optimize nutrient inputs and maximize plant uptake so the amount of nutrient losses is minimized. Although this may seem like a relatively easy task, the challenge in improving conversion efficiency is to accurately predict nutrient cycling and dynamics in forage systems.

As only a small proportion of the ingested nutrients are retained in animal products [13], nutrient recycling via animal wastes is an important soil fertility pathway in grazed pastures $[14,15]$. In addition to animal excreta, litter decomposition can also play an important role in terms of nutrient cycling in grazing systems [16]. A schematic representation of nutrient cycling in grazing systems is presented in Figure 1. Nutrients returned to the soil as animal excreta and/or litter decomposition can be utilized by plants but are also subject to losses.

Animal excreta play a major role in nutrient recycling in grazed pastures. Manure and urine chemical characteristics are determined by numerous factors, such as diet composition, animal species, and how the sampling is performed. In general, animal manure contains appreciable amounts of $\mathrm{N}$ and $\mathrm{P}$, while urine has significant concentrations of $\mathrm{N}$ and $\mathrm{K}$ that can be utilized by forages.

Cattle diets generally exceed animal $\mathrm{P}$ requirements by $25 \%$ to $40 \%$ [18], and a significant fraction ( $80 \%)$ of the $\mathrm{P}$ consumed is excreted in the feces due to the low bioavailability of dietary $\mathrm{P}$. Because the $\mathrm{N}: \mathrm{P}$ ratio of manures ( $4: 1$ to $5: 1$ ) typically does not match crop requirements 


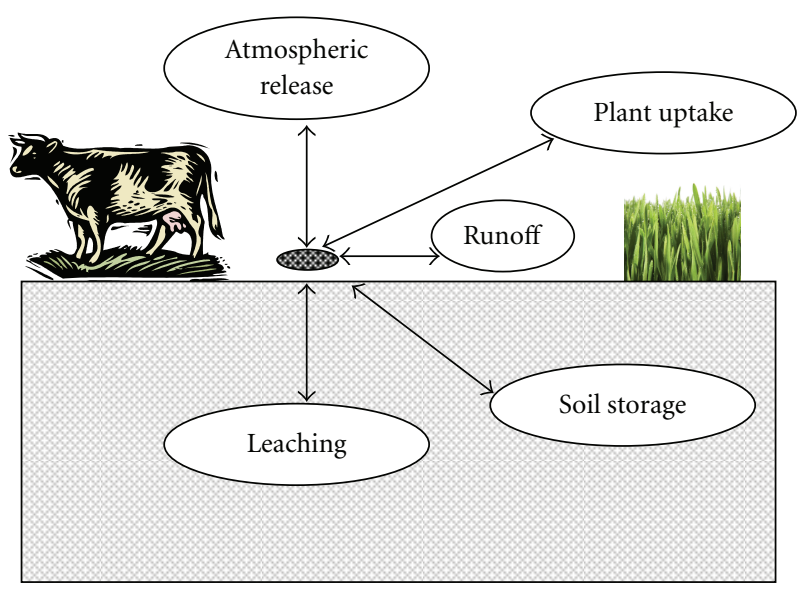

Figure 1: General components of nutrient cycling in grazed pastures (Adapted from [17]).

$(6: 1$ to $8: 1)[19,20]$, excess $P$ can easily accumulate in the soil as a result of long-term manure deposition. It has been estimated that soil $\mathrm{P}$ accumulation rates due to manure application in the USA and several European countries range from 8 to $40 \mathrm{~kg} \mathrm{Pha}^{-1} \mathrm{yr}^{-1}$ with an average rate of $22 \mathrm{~kg} \mathrm{Pha}^{-1} \mathrm{yr}^{-1}$ [21].

Nitrogen and $\mathrm{P}$ in animal excreta are present in various forms. For instance, the majority of the $\mathrm{N}$ present in the excreta occurs in organic forms, while manure $\mathrm{P}$ is primarily inorganic. This suggests that mineralization rates and nutrient availability in excreta depend on the nutrient and environmental conditions, such as soil moisture and temperature. [22] demonstrated that $\mathrm{P}$ availability in cattle manure could be as high as $100 \%$ and was comparable to inorganic $\mathrm{P}$ fertilizer.

A major concern relative to excreta deposition in grazed pastures is spatial distribution. Animal excreta are not returned uniformly to the soil, but rather a significant proportion of the nutrients may be concentrated in relatively small areas, generally near shade and water sources [23, 24]. Thus, animal behavior and grazing management can increase the heterogeneity of nutrient distribution in pastures. High excreta density in small areas of the pasture can contribute to soil nutrient buildup and subsequent transport to water bodies. In addition to environmental problems, losses of manure components as runoff and/or leaching have raised concerns regarding the impacts of animal excreta on human health [25].

Accumulation of nutrients as a result of long-term animal excreta deposition and/or fertilizer application represents an important environmental concern worldwide. Relatively efficient nutrient recycling in grassland systems can be promoted in pasture systems by using the soil, plant, and animal resources more efficiently. Management strategies such as altering animal feed composition, utilization of adequate fertilization programs, and maintaining appropriate animal stocking rates, can potentially increase nutrient recovery by the plants and, consequently, prevent environmental problems.

\section{Phosphorus Losses from Forage Systems}

With the increased concern over water quality and high costs of commercial fertilizer, research emphasis has been placed on re-evaluating nutrient management strategies that result in optimum forage production and yet have little or no negative effect on the environment. Phosphorus continues to be a major focus of research. While research has clearly demonstrated that $\mathrm{P}$ inputs are essential for profitable crop and livestock operations [5], transport of agricultural $\mathrm{P}$ has long been suggested as the major cause of eutrophication of surface waters $[20,21,26]$. The productivity and profitability of modern agriculture can be substantially increased by improving soil fertility conditions and forage production. However, recent research findings have shown that most economical forage production systems are not necessarily focused on maximum production [5, 27]. Instead, effort has been directed toward identifying fertilization practices that maintain sustainable forage yields [28] with minimal or no impacts on the environment. Research studies are continuing in this area to identify nutrient reduction technologies that can help producers reduce production costs as well as preserve the environment [29].

In addition to feed for herbivores, well-managed forages provide significant ecosystem services [30]. However, if improperly managed, pastures can be important nonpoint sources of pollution that can adversely impact water quality. This may occur because a significant proportion of nutrients imported to the pasture as fertilizer or animal feed is returned to the soil as animal excreta. Generally, about $70 \%$ to $90 \%$ of the $\mathrm{N}, \mathrm{P}$, and $\mathrm{K}$ ingested are recovered in the excreta and urine $[31,32]$. In general, areas where animals tend to congregate or have access to watercourses offer the highest risk for water pollution. As nutrients accumulate in the soil, subsequent off-site losses can occur $[33,34]$. The degree to which pastures can cause water quality concerns varies greatly depending on a number of factors such as soil type, fertilization regimen, stocking rate, and environmental conditions.

Recent investigations have shown that manure-impacted soils have considerable buffering capacity to resupply $\mathrm{P}$ into solution and can release significant amounts of $\mathrm{P}$ over time [35]. Under intensive grazing, where concentration of manure occurs in localized areas, soil nitrate concentrations may also be increased. Unlike grazed pastures where nutrient removal is minimal and considerable amounts of the nutrients absorbed by the plants are returned as excreta, large amounts of $\mathrm{N}, \mathrm{P}$, and $\mathrm{K}$ are removed in harvested forage systems. To sustain adequate forage production, harvested forage systems require significant amounts of fertilizer to replenish nutrient removal. A general shortcoming of most fertilizers is their high solubility in the soil, which makes nutrients applied as fertilizers subject to losses. For instance, nitrate is found free in the soil solution and can be lost within a short time after application if not taken up by the roots. The purpose of efficient and profitable nutrient application in both harvested forage and grazing systems is to obtain maximum utilization rates of the applied fertilizer by the 
forage. Losses of nutrients not only add to production costs but they can also have negative environmental consequences.

Losses via runoff and leaching are the major pathways by which nutrients are transported from forage systems. Among all the nutrients, $\mathrm{P}$ followed by $\mathrm{N}$ have been historically identified as the major environmental concerns with respect to water quality [36]. While $\mathrm{P}$ is perhaps of greater concern in terms of ecological quality of fresh waters, nitrate- $\mathrm{N}$ is of concern because it renders water unsuitable for drinking without further treatment [36]. Phosphorus concentrations as low as $10 \mu \mathrm{g} \mathrm{P} \mathrm{L}^{-1}$ have been suggested to reduce water quality [37]. Numerous studies have shown that accelerated eutrophication of fresh water is commonly associated with transport of $\mathrm{N}$ and $\mathrm{P}$ from agricultural areas [26, 36, 37]. This occurs because $\mathrm{N}$ and $\mathrm{P}$ are typically limiting nutrients in aquatic systems [38]. As $\mathrm{N}$ and $\mathrm{P}$ concentrations increase, primary productivity in water bodies is stimulated promoting algae bloom, fish kill, and new species invasion.

Eutrophication has been recognized as the primary cause of water impairment in the United States [39]. Considerable effort has been placed on identifying effective best management practices (BMPs) that can reduce and/or minimize nutrient transport from agricultural systems to surface waters. Effective BMPs should encompass the adoption of short-term management practices to reduce the risk of nutrient transport and long-term regimens to minimize nutrient inputs. Among the most common BMPs recommended for pastures and rangelands are (i) maintenance of adequate vegetative cover, (ii) utilization of sustainable nutrient management practices, (iii) use of riparian buffer zones, and (iv) restoration of isolated wetlands on pastures. In addition, chemical amendments have been suggested to reduce nutrient mobility in the soil and prevent leaching and runoff losses. Reference [35] observed that addition of aluminum water treatment residuals to P-impacted soils could reduce $\mathrm{P}$ leaching by as much as $99.8 \%$ compared to control treatments. Reference [40] have also shown that P remained nonlabile after 7.5 years of amendment application suggesting the long-term stability of water treatmentimmobilized P.

Nutrient conservation plans are an important first step to improve nutrient utilization efficiency in forage systems. Considerable work has been done to develop conservation plans that address both the agronomic and environmental aspects of forage production. Successful conservation plans should take into account the need to maintain a thriving and economically viable agricultural industry. This can be an extremely useful first-step tool that will help ranchers with management decisions that can impact forage production, costs, and the environment.

\section{Experimental Methods to Assess Nutrient Loss}

A variety of experimental methods, from plot to watershed scale, has been used to evaluate nutrient transport from agricultural soils. However, because of the lack of uniformity in the experimental conditions, the interpretation and comparison of results among sites are often limited. Models of varying complexity have also been used to predict the environmental impacts of nutrient transport from agricultural systems [41-44].

The impacts of animal manure and fertilizer application on water quality have been clearly demonstrated in numerous small-scale studies [19-21]. These results generally indicate that nutrient losses increase as the application rates increased. In addition, concentrations of nutrients in runoff and leachates are generally greater immediately after fertilizer and/or manure application [45]. Research has clearly demonstrated that experimental conditions such as days after manure and/or fertilizer application, application method (surface versus incorporated), nutrient source, rainfall intensity, and initial soil moisture can affect water quality results [46-48]. Despite the importance of spatial and temporal scale on the processes controlling nutrient transport, relatively few studies have evaluated the impacts of nutrient application and water quality problems at watershed scale.

Field runoff plots of various sizes receiving natural and/or simulated rainfall have been frequently used to assess nutrient losses [49-51]. Although field runoff plots are not expected to truly represent field conditions, they have some advantages over watershed studies because they provide more controlled conditions [52]. Runoff boxes, also known as packed boxes, have also been commonly used to quantify runoff P. [52] compared field runoff plots (2-m long by 1-m wide) and runoff boxes (1-m long by $20-\mathrm{cm}$ wide and $5-\mathrm{cm}$ deep) and observed that infiltration rates and runoff volumes were significantly different between the two methods. These authors indicated that greater infiltration was observed in the field runoff plots, while greater runoff volume was found in the runoff boxes because of the limited infiltration due to the box depth. Similarly to runoff plots, runoff boxes are not representative of field conditions, and caution should be exercised when interpreting and extrapolating results to field conditions. Factors such as depth of the box, hydrology of packed soil, and vegetative cover can affect the results. Because of the differences in the hydrologic variables among different research protocols, it is expected that the results will be highly method dependent. In order to minimize the variability associated with the experimental conditions, the National P Research Project has established a protocol for conducting rainfall simulations [53]. This includes the dimensions of the rainfall simulator and runoff boxes and rainfall intensity and duration. Despite some limitations, runoff boxes can provide important information relative to $\mathrm{P}$ availability coefficients for various $\mathrm{P}$ sources [54].

Although surface runoff has long been viewed as the major pathway by which $\mathrm{P}$ is transported from pastures, subsurface flow can also play a major role in terms of $\mathrm{P}$ transport. Significant $\mathrm{P}$ leaching has been documented in sandy soils, with low nutrient sorbing capacity [35, 55]. Different methods have been employed to estimate $\mathrm{P}$ leaching potential in agricultural soils. Most common leaching experiments include laboratory, greenhouse, and field approaches. Soil columns, lysimeters, suction cups, 
leachate sampling plates, and leachate buckets are some of the instruments used in leaching studies. Similarly to runoff experiments, the interpretation of leachate nutrient concentrations can be highly influenced by the experimental design. Therefore, nutrient leaching losses obtained from any given study are not always directly translated into surface water concerns. Column studies can provide useful information relative to the potential for vertical movement of nutrients, but due to the role of soil structure and lack of lateral water movement such results can not be directly extrapolated to field conditions. Rather, leaching studies can provide general trends regarding subsurface nutrient transport under very specific conditions.

\section{Assessment Tools to Predict Risks for P Losses}

Although soil test $\mathrm{P}$ has been frequently used to determine the agronomic response of forage crops to $\mathrm{P}$ fertilization, it cannot predict environmental $\mathrm{P}$ losses. This is because rainfall, erosion potential, drainage, distance from the receiving watercourse, and management factors can also affect the likelihood of $\mathrm{P}$ being lost from agricultural fields. As soil test alone can not predict $\mathrm{P}$ transport, various indicators of $\mathrm{P}$ liability have been proposed in different regions in the US and European countries as tools to efficiently assess the risk of $\mathrm{P}$ pollution. Typically $\mathrm{P}$ assessment tools take into consideration transport factors as well as $\mathrm{P}$ source and management. The $\mathrm{P}$ index, for instance, was developed by 49 states in the US as a valuable nutrient management tool to predict the risk of $\mathrm{P}$ loss from agricultural fields $[54,56]$. A variety of sophisticated $\mathrm{P}$ index have also been used in Europe to identify high risks sites [57-59]. The various $\mathrm{P}$ indices typically incorporate soil chemical and physical attributes and the characteristics of the watershed to address the site-specific potential for $\mathrm{P}$ losses. The main purpose of the $\mathrm{P}$ index is to help planners and decision makers involved in designing nutrient management plans for agriculture systems. This concept assumes that sites are subjected to different management practices and can exhibit different vulnerability to $\mathrm{P}$ transport. Based on the P-index concept, a site can be classified as a very high, high, medium, or low risk for environmental $\mathrm{P}$ losses, and best management practices that can effectively minimize $\mathrm{P}$ transport can be selected for specific fields.

Unlike the P index that takes into consideration transport factors, more simplistic approaches have also been widely utilized as indicators of potential environmental problem associated with $\mathrm{P}$ transport. The degree of $\mathrm{P}$ saturation (DPS) concept, originally developed in the Netherlands, compares the percentage of $\mathrm{P}$ saturation of the soil profile and the $P$ concentration in the soil solution [60]. The DPS was originally developed based on the ratio of oxalate extractable $\mathrm{P}$ to the sum of $\mathrm{Fe}$ and $\mathrm{Al}$. This approach assumes that the ratio between $\mathrm{P}, \mathrm{Al}$, and $\mathrm{Fe}$ concentrations can be used an indicator of soil's potential to release $\mathrm{P}[61,62]$. Because of analytical problems associated with oxalate extraction, [63] demonstrated the DPS can also be calculated as a function of Mehlich-1 P, Fe, and Al.
Another tool used to estimate potential risk for $\mathrm{P}$ losses is the soil P storage capacity (SPSC) concept developed by [62]. The SPSC is calculated based on a threshold P saturation ratio (PSR) of 0.15 [63]. The PSR is calculated as the molar ratio of $\mathrm{P}$ to Fe plus $\mathrm{Al}$. The formula used to calculate SPSC is as follows:

$$
\mathrm{SPSC}=(0.15-\mathrm{PSR})^{*} \operatorname{Mehlich} 1(\mathrm{Fe}+\mathrm{Al})^{*} 2,
$$

where PSR is the P saturation ratio of the soil sample for which SPSC is being calculated.

The SPSC is expressed in milligrams of $\mathrm{P}$ that can be added to a kilogram of soil $\left(\mathrm{mg} \mathrm{kg}^{-1}\right)$ before a threshold PSR of 0.15 is reached. The 0.15 coefficient is a threshold PSR value that corresponds to the critical $\mathrm{P}$ solution concentration of $0.10 \mathrm{mg} / \mathrm{L}$ [62]. The critical P solution concentration of $0.10 \mathrm{mg} / \mathrm{L}$ corresponds to the guideline established by USEPA for streams [39]. Positive values of SPSC mean that a P source can be applied safely; negative values mean that $\mathrm{P}$ additions can result in $\mathrm{P}$ losses from the soil that can contaminate groundwater. Differences between extractants (oxalate versus a soil test $\mathrm{P}$ such as Mehlich-1) in the calculation of SPSC require a calibration factor; that factor is approximately 2 when Mehlich-1 parameters are used [64]. The SPSC can also be calculated using Mehlich-3$\mathrm{P}, \mathrm{Fe}$, and $\mathrm{Al}$. However, a calibration factor is not available for SPSC calculations using Mehlich-3 parameters at this time. [63] showed that the threshold PSR calculated from Mehlich3 parameters is similar to that calculated using oxalate and Mehlich-1 P, Fe, and $\mathrm{Al}$ data.

The SPSC captures the risk of unimpacted soils that have low $\mathrm{P}$ sorption capacity. For example, Aquods of the southeastern USA coastal plain generally have 99\% quartz sand in the surface horizons and negligible P retention [55]. Evaluation of a freshly cleared field for an Aquod would typically show low soil test $\mathrm{P}$ concentrations $\left(<5 \mathrm{mg} \mathrm{kg}^{-1}\right)$, which could be erroneously interpreted as low environmental risk. However, a capacity-based assessment such as the SPSC can reveal the limited P sorbing capacity of the soil and provides a basis for how long the site could be safely used for further P application. Hence, the SPSC has the potential to enable prediction of the lifespan of a $\mathrm{P}$ application site with knowledge of the P-loading schedule as demonstrated by [64]. Results support the validity of SPSC as a means of estimating $\mathrm{P}$ loading rates that pose minimum environmental threat for sandy soils. From an analysis of over 750 soil samples collected in the field, [65] showed that as long as SPSC is positive, water soluble P (WSP) in the soil is minimum, but WSP increases dramatically as SPSC becomes negative. Controlled column experiments with various $\mathrm{P}$ impact levels and leachate analyses for $\mathrm{P}$ showed a similar response [64].

\section{Conclusions}

There continue to be uncertainties regarding interrelationships between $\mathrm{P}$ management and water quality issues in grazingland ecosystems. Ideally, studies on nutrient transport should assess nutrient dynamics in the soil and 
mechanisms by which nutrients are subsequently transported to water surface and groundwater. The pathways of nutrient losses in pasture systems can be extremely complicated, so continued research efforts should be placed on better understanding $\mathrm{P}$ dynamics in these systems, and how $\mathrm{P}$ management can be managed to address both agronomic and environmental aspects. While low-input systems may seldom cause water quality problems, pastures excessively fertilized and those associated with high stocking rates may pose serious impacts on surface and subsurface water contamination. However, when compared to other agricultural systems, properly managed grasslands usually represent less risk than row crops and may not be different from native ecosystems in terms of environmental impacts.

As agriculture continues to modernize and intensify, public concerns about the impacts of plant nutrients on environmental quality will likely increase. Because of the rapid population growth in many parts of the world, agriculture and urban societies will increasingly compete for finite water supplies. Managing water quality protection and profitable agriculture will be a major challenge for the next generations.

\section{References}

[1] D. G. Blevins and D. J. Barker, "Nutrients and water in forage crops," in Forages: The Science of Grassland Agriculture, R. F. Barnes, et al., Ed., pp. 67-80, Blackwell, Ames, Iowa, USA, 2007.

[2] M. B. Adjei and J. E. Rechcigl, "Bahiagrass production and nutritive value as affected by domestic wastewater residuals," Agronomy Journal, vol. 94, no. 6, pp. 1400-1410, 2002.

[3] G. C. Sigua, M. J. Williams, S. W. Coleman, and R. Starks, "Nitrogen and phosphorus status of soils and trophic state of lakes associated with forage-based beef cattle operations in Florida," Journal of Environmental Quality, vol. 35, no. 1, pp. 240-252, 2006.

[4] J. C. Capece, K. L. Campbell, P. J. Bohlen, D. A. Graetz, and K. M. Portier, "Soil phosphorus, cattle stocking rates, and water quality in subtropical pastures in Florida, USA," Rangeland Ecology and Management, vol. 60, no. 1, pp. 19-30, 2007.

[5] J. E. Rechcigl, G. G. Payne, A. B. Bottcher, and P. S. Porter, "Reduced P application on bahiagrass and water quality," Agronomy Journal, vol. 84, pp. 463-468, 1992.

[6] G. C. Sigua, R. K. Hubbard, and S. W. Coleman, "Quantifying phosphorus levels in soils, plants, surface water, and shallow groundwater associated with bahiagrass-based pastures," Environmental Science and Pollution Research, vol. 17, pp. 210-219, 2010.

[7] J. E. Rechcigl, P. Mislevy, and H. Ibrikci, "Response of established bahiagrass to broadcast lime and phosphorus," Journal of Production Agriculture, vol. 8, no. 2, pp. 249-253, 1995.

[8] F. Adams, "Crop response to lime in the southern United States," in Soil Acidity and Liming, Mong, F. Adams, Ed., vol. 12, American Society of Agronomy, Madison, Wis, USA, 1984.

[9] R. Mylavarapu, D. Wright, G. Kidder, and C. G. Chambliss, "UF/IFAS Standardized fertilization recommendations for agronomic crops," Cooperative Extension Service, IFAS, University of Florida. SL129, 2007, http://edis.ifas.ufl.edu/SS163.
[10] M. L. Silveira, J. M. Vendramini, L. E. Sollenberger, C. L. Mackowiak, and Y. C. Newman, "Tissue analysis as a nutrient management tool for bahiagrass pasture," Cooperative Extension Service, IFAS, University of Florida. SS475, 2007, http://edis.ifas.ufl.edu/SS475.

[11] C. L. Mondart Jr., H. E. Harris, R. H. Brupbacher Jr., and J. E. Sedberry, "Influence of annual applications of phosphorus on the yield and chemical composition of common bermudagrass and on the chemical composition of a Bowie soil," Louisiana Agricultural Experiment Station Bulletin, no. 684, 1974.

[12] K.A. Kelling and J. E. Matocha, "Plant analysis as an aid in fertilizing forage crops," in Soil Testing and Plant Analysis, R. L. Westerman, Ed., pp. 603-643, Soil Science of Americ, Madison, Wis, USA, 1990.

[13] P. R. Peterson and J. R. Gerrish, "Grazing systems and spatial distribution of nutrients in pastures: livestock management considerations," in Nutrient Cycling in Forage Systems, R. E. Joost and C. A. Roberts, Eds., pp. 203-212, Potash and Phosphate Institute and Foundation for Agron Research, Columbia, MO, USA; PPI, Norcross, Ga, USA, 1996.

[14] F. M. Rouquette, J. E. Matocha, and R. L. Duble, "Recycling and recovery of nitrogen, phosphorus, and potassium by Coastal bermudagrass: II. Under grazing conditions with two stocking rates," Journal of Environmental Quality, vol. 2, pp. 129-132, 1973.

[15] A. S. Dahlin, U. Emanuelsson, and J. H. McAdam, "Nutrient management in low input grazing-based systems of meat production," Soil Use and Management, vol. 21, pp. 122-131, 2005.

[16] J. C. B. Dubeux Jr., L. E. Sollenberger, B. W. Mathews, J. M. Scholberg, and H. Q. Santos, "Nutrient cycling in warmclimate grasslands," Crop Science, vol. 47, no. 3, pp. 915-928, 2007.

[17] D. R. Edwards, "Recycling livestock manure on pastures," in Nutrient Cycling in Forage Systems, R. E. Joost and C. A. Roberts, Eds., pp. 45-63, Potash and Phosphate Institute and Foundation for Agron Research, Columbia, MO, USA, 1996, PPI, Norcross, Ga, USA, 1996.

[18] K. F. Knowlton and R. Kohn, "Feeding management to reduce phosphorus losses from dairy farms," in Proceedings of the Mid-Atlantic Dairy Management Conference, pp. 94108, Pennsylvania State University Park, Camp Hill, Pa, USA, February 1999.

[19] B. Eghball, "Leaching of phosphorus fractions following manure or compost application," Communications in Soil Science and Plant Analysis, vol. 34, no. 19-20, pp. 2803-2815, 2003.

[20] A. N. Sharpley, S. C. Chapra, R. Wedepohl, J. T. Sims, T. C. Daniel, and K. R. Reddy, "Managing agricultural phosphorus for protection of surface waters: issues and options," Journal of Environmental Quality, vol. 23, no. 3, pp. 437-451, 1994.

[21] S. R. Carpenter, N. F. Caraco, D. L. Correll, R. W. Howarth, A. N. Sharpley, and V. H. Smith, "Nonpoint pollution of surface waters with phosphorus and nitrogen," Ecological Applications, vol. 8, no. 3, pp. 559-568, 1998.

[22] B. Eghball, B. J. Wienhold, B. L. Woodbury, and R. A. Eigenberg, "Plant availability of phosphorus in swine slurry and cattle feedlot manure," Agronomy Journal, vol. 97, no. 2, pp. 542-548, 2005.

[23] B. W. Mathews, L. E. Sollenberger, P. Nkedi-Kizza, L. A. Gaston, and H. D. Hornsby, "Soil sampling procedures for monitoring potassium distribution in grazed pastures," Agronomy Journal, vol. 86, no. 1, pp. 121-126, 1994. 
[24] B. W. Mathews, L. E. Sollenberger, and J. P. Tritschler II, "Grazing systems and spatial distribution of nutrients in pastures: soil considerations," in Nutrient Cycling in Forage Systems, R. E. Joost and C. A. Roberts, Eds., pp. 213-229, Potash and Phosphate Institute and Foundation for Agron Research, Columbia, MO, USA; PPI, Norcross, Ga, USA, 1996.

[25] C. J. Johnson, P. A. Bonrud, T. L. Dosch, et al., "Fatal outcome of methemoglobinemia in an infant," Journal of the American Medical Association, vol. 257, no. 20, pp. 2796-2797, 1987.

[26] A. N. Sharpley and A. D. Halvorson, Soil Process and Water Quality, Lewis Publishers, Boca Raton, Fla, USA, 1994.

[27] J. E. Rechcigl and A. B. Boucher, "Fate of phosphorus on bahiagrass (Paspalum notatum) pastures," Ecological Engineering, vol. 5, no. 2-3, pp. 247-259, 1995.

[28] M. L. Silveira, A. K. Obour, J. M. Vendramini, and L. E. Sollenberger, "Using tissue analysis as a tool to predict bahiagrass phosphorus fertilization requirement," Journal of Plant Nutrition. In press.

[29] A. K. Obour, M. L. Silveira, J. M. B. Vendramini, L. E. Sollenberger, G. A. O'Connor, and J. W. Jawitz, “Agronomic and environmental impacts of phosphorus fertilization of low input bahiagrass systems in Florida," Agronomy Journal. In press.

[30] D. R. Keeney and M. A. Sanderson, "Forages and the environment," in Forages: The Science of Grassland Agriculture, R. F. Barnes, et al., Ed., pp. 167-176, Blackwell, Ames, Iowa, USA, 2007.

[31] R. J. Haynes and P. H. Williams, "Nutrient cycling and soil fertility in grazed pasture ecosystem," Advances in Agronomy, vol. 49, pp. 119-199, 1993.

[32] P. H. Williams and R. J. Haynes, "Influence of improved pastures and grazing animals on nutrient cycling within $\mathrm{New}$ Zealand soils," New Zealand Journal of Ecology, vol. 14, pp. 4957, 1990.

[33] A. N. Sharpley, P. J. A. Kleinman, R. W. McDowell, M. Gitau, and R. B. Bryant, "Modeling phosphorus transport in agricultural watersheds: processes and possibilities," Journal of Soil and Water Conservation, vol. 57, no. 6, pp. 425-439, 2002.

[34] J. M. Novak, D. W. Watts, P. G. Hunt, and K. C. Stone, "Phosphorus movement through a Costal Plain soil after a decade of intensive swine manure application," Journal of Environmental Quality, vol. 29, pp. 1310-1315, 2000.

[35] M. L. Silveira, M. K. Miyittah, and G. A. O'Connor, "Phosphorus release from a manure-impacted spodosol: effects of a water treatment residual," Journal of Environmental Quality, vol. 35, no. 2, pp. 529-541, 2006.

[36] P. J. A. Withers and E. I. Lord, "Agricultural nutrient inputs to rivers and groundwaters in the UK: policy, environmental management and research needs," Science of the Total Environment, vol. 282-283, pp. 9-24, 2002.

[37] G. M. Pierzynski, J. T. Sims, and G. F. Vance, Soils and Environmental Quality, CRC Press, Boca Raton, Fla, USA, 2005.

[38] J. K. Syers, R. F. Harris, and D. E. Armstrong, "Phosphate chemistry in lake sediments," Journal of Environmental Quality, vol. 2, pp. 1-13, 1973.

[39] USEPA, "Environmental indicators of water quality in the United States," EPA 841-R-96-002, U.S. Government Printing Office, Washington, DC, USA, 1996.

[40] S. Agyin-Birikorang, G. A. O'Connor, L. W. Jacobs, K. C. Makris, and S. R. Brinton, "Long-term phosphorus immobilization by a drinking water treatment residual," Journal of Environmental Quality, vol. 36, no. 1, pp. 316-323, 2007.
[41] M. G. Hutchins, S. G. Anthony, R. A. Hodgkinson, and P. J. A. Withers, "Modularised process-based modelling of phosphorus loss at farm and catchment scale," Hydrology and Earth System Sciences, vol. 6, no. 6, pp. 1017-1030, 2002.

[42] P. S. Davison, P. J. A. Withers, E. I. Lord, M. J. Betson, and J. Strömqvist, "PSYCHIC-a process-based model of phosphorus and sediment mobilisation and delivery within agricultural catchments. Part 1: model description and parameterisation," Journal of Hydrology, vol. 350, no. 3-4, pp. 290302, 2008.

[43] D. E. Radcliffe, J. Freer, and O. Schoumans, "Diffuse phosphorus models in the United States and Europe: their usages, scales, and uncertainties," Journal of Environmental Quality, vol. 38, no. 5, pp. 1956-1967, 2009.

[44] L. M. Pease, P. Oduor, and G. Padmanabhan, "Estimating sediment, nitrogen, and phosphorous loads from the Pipestem Creek watershed, North Dakota, using AnnAGNPS," Computers and Geosciences, vol. 36, no. 3, pp. 282-291, 2010.

[45] B. Eghball and J. E. Gilley, "Phosphorus and nitrogen in runoff following beef cattle manure or compost application," Journal of Environmental Quality, vol. 28, no. 4, pp. 1201-1210, 1999.

[46] D. R. Edwards and T. C. Daniel, "Drying interval effects on runoff from fescue plots receiving swine manure," Transactions of the American Society of Agricultural Engineers, vol. 36, no. 6, pp. 1673-1678, 1993.

[47] D. R. Edwards, T. C. Daniel, P. A. Moore Jr., and A. N. Sharpley, "Solids transport and erodibility of poultry litter surface-applied to fescue," Transactions of the American Society of Agricultural Engineers, vol. 37, no. 3, pp. 771-776, 1994.

[48] I. C. Daverede, A. N. Kravchenko, R. G. Hoeft et al., "Phosphorus runoff from incorporated and surface-applied liquid swine manure and phosphorus fertilizer," Journal of Environmental Quality, vol. 33, no. 4, pp. 1535-1544, 2004.

[49] A. N. Sharpley, T. Daniel, R. Qright, et al., "National research project to identify sources of agricultural phosphorus loss," Better Crops, vol. 83, pp. 12-14, 1999.

[50] A. N. Sharpley, P. J. A. Kleinman, R. J. Wright, et al., "The National Phosphorus Project: addressing the interface of agriculture and environmental phosphorus management in the USA. Section 2.3. Indicators for environmental performance," in Agricultural Effects on Ground and Surface Water: Research at the Edge of Science and Society, F. Steenvoorden and J. Willems, Eds., vol. 273, pp. 95-100, International Association of Scientific Hydrology Press, Wallingford, UK, 2002.

[51] D. D. Tarkalson and R. L. Mikkelsen, "Runoff phosphorus losses as related to phosphorus source, application method, and application rate on a Piedmont soil," Journal of Environmental Quality, vol. 33, no. 4, pp. 1424-1430, 2004.

[52] P. J. A. Kleinman, A. N. Sharpley, T. L. Veith, R. O. Maguire, and P. A. Vadas, "Evaluation of phosphorus transport in surface runoff from packed soil boxes," Journal of Environmental Quality, vol. 33, no. 4, pp. 1413-1423, 2004.

[53] National Phosphorus Research Project, "National research project for simulated rainfall-surface runoff studies," North Carolina State University, Raleigh, NC, USA 2001, http://www.sera17.ext.vt.edu/Documents/National_P _protocol.pdf.

[54] A. N. Sharpley, J. L. Weld, D. B. Beegle et al., "Development of phosphorus indices for nutrient management planning strategies in the United States," Journal of Soil and Water Conservation, vol. 58, no. 3, pp. 137-152, 2003.

[55] W. G. Harris, R. D. Rhue, G. Kidder, R. B. Brown, and R. Littell, "Phosphorus retention as related to morphology 
of sandy coastal plain soil materials," Soil Science Society of America Journal, vol. 60, no. 5, pp. 1513-1521, 1996.

[56] C. S. Snyder, T. W. Bruulsema, A. N. Sharpley, and D. B. Beegle, "Site-specific use of the environmental PhosphorusIndex concept," in Site Specific Management Guidelines, SSMG1, Potash and Phosphate Instituteitute, Norcross, Ga, USA, 1999.

[57] H. E. Andersen and B. Kronvang, "Modifying and evaluating a P index for Denmark," Water, Air, and Soil Pollution, vol. 174, no. 1-4, pp. 341-353, 2006.

[58] U. Buczko and R. O. Kuchenbuch, "Phosphorus indices as risk-assessment tools in the U.S.A. and Europe-a review," Journal of Plant Nutrition and Soil Science, vol. 170, no. 4, pp. 445-460, 2007.

[59] G. Heckrath, M. Bechmann, P. Ekholm, B. Ulén, F. Djodjic, and H. E. Andersen, "Review of indexing tools for identifying high risk areas of phosphorus loss in Nordic catchments," Journal of Hydrology, vol. 349, no. 1-2, pp. 68-87, 2008.

[60] S. E. A. T. M. van der Zee and W. H. van Riemsdijk, "Model for long-term phosphate reaction kinetics in soil," Journal of Environmental Quality, vol. 17, no. 1, pp. 35-41, 1988.

[61] P. S. Hooda, A. R. Rendell, and A. C. Edwards, "Relating soil phosphorus indices to potential phosphorus release to water," Journal of Environmental Quality, vol. 29, no. 4, pp. 1166$1171,2000$.

[62] V. D. Nair and W. G. Harris, "A capacity factor as an alternative to soil test phosphorus in phosphorus risk assessment," New Zealand Journal of Agricultural Research, vol. 47, no. 4, pp. 491-497, 2004.

[63] V. D. Nair, K. M. Portier, D. A. Graetz, and M. L. Walker, "An environmental threshold for degree of phosphorus saturation in sandy soils," Journal of Environmental Quality, vol. 33, no. 1, pp. 107-113, 2004.

[64] M. Chrysostome, V. D. Nair, W. G. Harris, and R. D. Rhue, "Laboratory validation of soil phosphorus storage capacity predictions for use in risk assessment," Soil Science Society of America Journal, vol. 71, no. 5, pp. 1564-1569, 2007.

[65] V. D. Nair, S. G. Haile, G.-A. Michel, and P. K. R. Nair, "Environmental quality improvement of agricultural lands through silvopasture in Southeastern United States," Scientia Agricola, vol. 64, no. 5, pp. 513-519, 2007. 


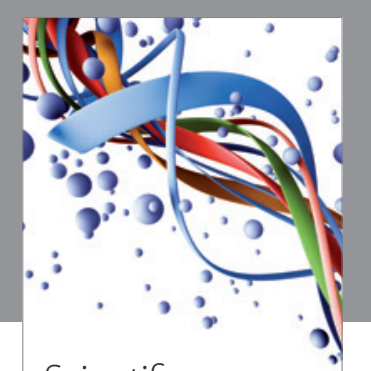

Scientifica
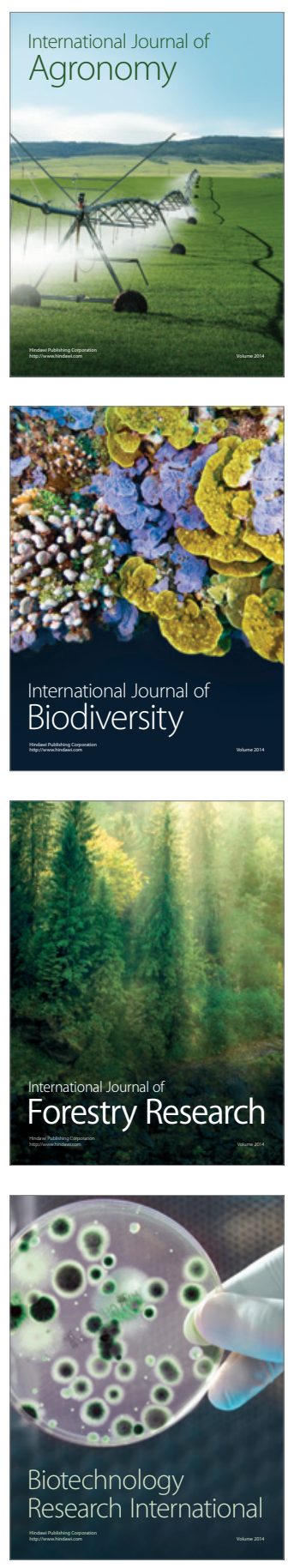
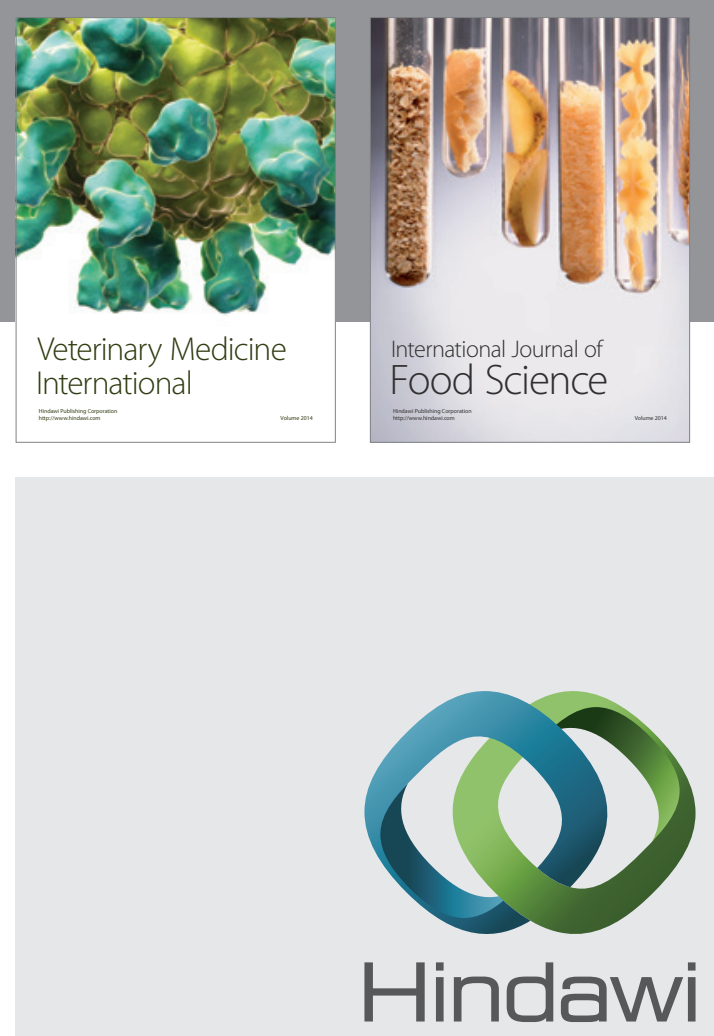

Submit your manuscripts at

http://www.hindawi.com
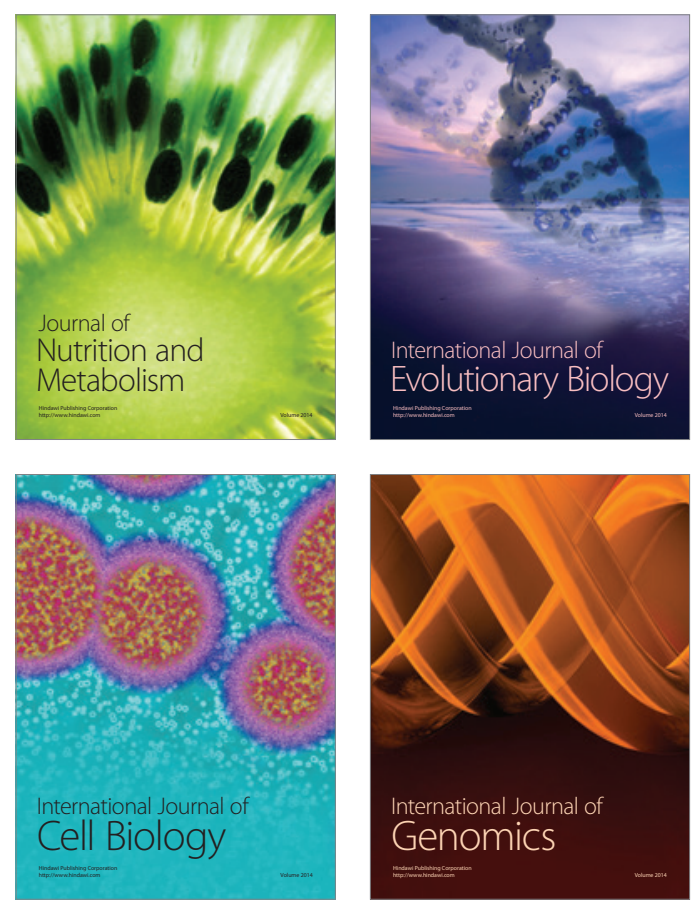
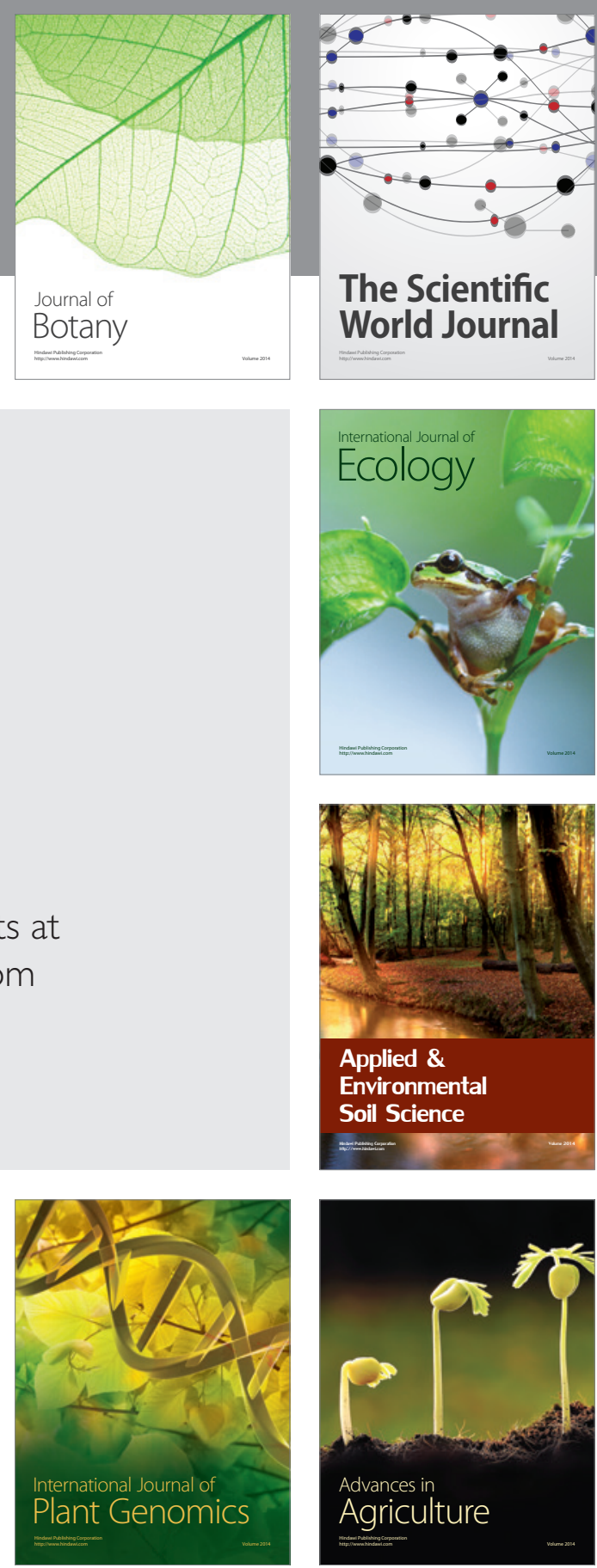

The Scientific World Journal
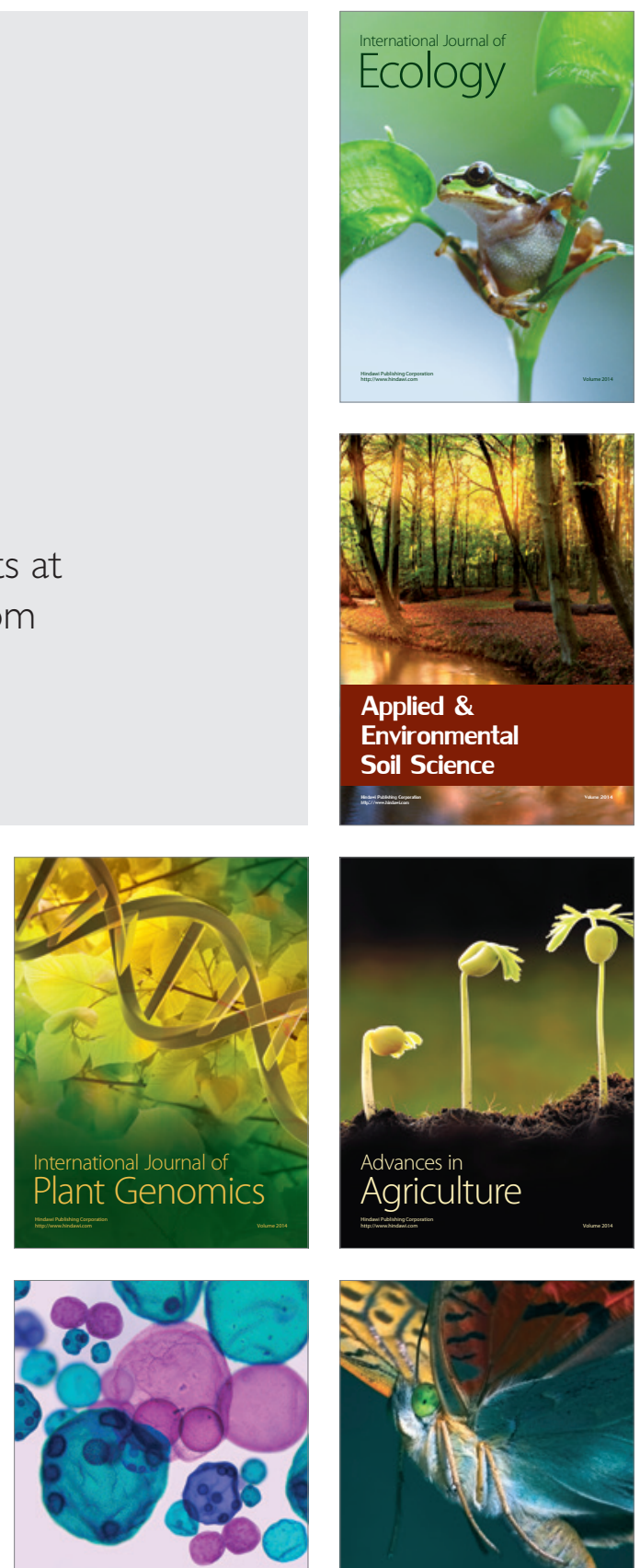

International Journal of Microbiology

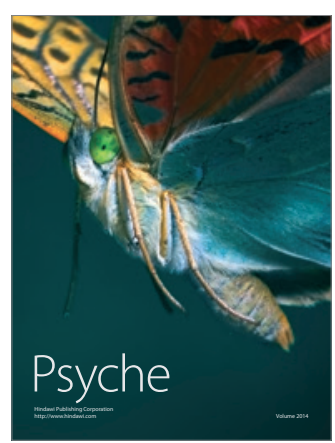

